\title{
Politics of waiting
}

\section{MANCHESTER

Manchester University Press 


\section{POLITICAL ETHNOGRAPHY}

The Political Ethnography series is an outlet for ethnographic research into politics and administration and builds an interdisciplinary platform for a readership interested in qualitative research in this area. Such work cuts across traditional scholarly boundaries of political science, public administration, anthropology, social policy studies and development studies and facilitates a conversation across disciplines. It will provoke a re-thinking of how researchers can understand politics and administration.

\section{Previously published titles}

The absurdity of bureaucracy: How implementation works Nina Holm Vohnsen 


\title{
Politics of waiting
}

Workfare, post-Soviet austerity and

the ethics of freedom

\author{
Liene Ozolina
}

Manchester University Press 
Copyright (C) Liene Ozoliņa 2019

The right of Liene Ozolina to be identified as the author of this work has been asserted by her in accordance with the Copyright, Designs and Patents Act 1988.

Published by Manchester University Press

Altrincham Street, Manchester M1 7JA

www.manchesteruniversitypress.co.uk

British Library Cataloguing-in-Publication Data

A catalogue record for this book is available from the British Library

ISBN 9781526126252 hardback

First published 2019

The publisher has no responsibility for the persistence or accuracy of URLs for any external or thirdparty internet websites referred to in this book, and does not guarantee that any content on such websites is, or will remain, accurate or appropriate.

Typeset by

Deanta Global Publishing Services 